\title{
Anticipation in an Indo-Canadian family with Crohn's disease
}

\author{
Hugh J Freeman $\mathrm{MD}^{1}$, Noel B Hershfield MD ${ }^{2}$
}

HJ Freeman, NB Hershfield. Anticipation in an IndoCanadian family with Crohn's disease. Can J Gastroenterol 2001;15(10):695-698. Genetic anticipation, associated elsewhere with monogenic neurological disorders, has been hypothesized to be present in familial forms of Crohn's disease. Usually, with studies of parent-child pairs, the parent who is initially diagnosed is older at the onset of disease than the child. With each successive generation, an apparent increase in disease severity or behaviour occurs. This phenomenon is believed to have a molecular basis. In the present report, an Indo-Canadian family with Crohn's disease is described. In all members of the family, disease was diagnosed only after prolonged residence in Canada, supporting the view that Crohn's disease arises in individuals with a genetic predisposition following exposure to some, as yet unknown, common environmental factor. Three siblings with Crohn's disease, first diagnosed between ages 15 and 27 years, or six to 11 years after arrival in Canada, had phenotypically concordant disease localized in the ileum and colon, with fistulizing complications, including perianal sepsis. Crohn's disease was only diagnosed in the father at the age of 76 years, almost three decades after his arrival in Canada. His disease was localized to the ileum and had a fibrostenosing behaviour. This is the first reported instance of familial Crohn's disease in an immigrant population, illustrating potential biases in genetically based studies of Crohn's disease that rely solely on phenotypic expression.

Key Words: Familial Crohn's disease; Genetic anticipation; Genetic markers; Inflammatory bowel disease

\section{Famille indo-canadienne atteinte de la maladie de Crohn et anticipation génétique}

RÉSUMÉ : On croit que l'anticipation génétique, associée à certains troubles neurologiques monogéniques, est aussi présente dans les formes familiales de la maladie de Crohn. Dans les études parent-enfant, le parent initialement atteint est souvent plus âgé que l'enfant au moment de la pose du diagnostic. De plus, la maladie semble gagner en gravité à chaque génération. Le phénomène aurait un fondement moléculair. Le présent article fait état d'une famille indo-canadienne, atteinte de la maladie de Crohn. Cette dernière a été diagnostiquée chez tous les membres de la famille après un séjour prolongé au Canada, ce qui étaye l'hypothèse selon laquelle la maladie de Crohn se manifeste chez des personnes qui sont d'abord prédisposées génétiquement, puis exposées à un facteur environnemental courant, encore inconnu. Trois frères et sœurs qui étaient âgés entre 15 et 27 ans au moment de la pose du diagnostic, soit de 6 à 11 ans après leur arrivée au Canada, souffraient de la même forme de la maladie : atteinte de l'iléon et du côlon, fistules et septicémie d'origine périanale. La maladie de Crohn n'a été diagnostiquée chez le père qu'à l'âge de 76 ans, presque trois décennies après son arrivée au Canada. Elle touchait l'iléon et a évolué vers une sténose par transformation fibreuse. Il s'agit du premier cas signalé de maladie de Crohn familiale chez des immigrants; cela montre bien les risques de biais que peuvent comporter les études génétiques qui reposent uniquement sur l'expression phénotypique de la maladie.

${ }^{1}$ Department of Medicine (Gastroenterology), University of British Columbia, Vancouver, British Columbia, and ${ }^{2}$ Department of Medicine (Gastroenterology), University of Calgary, Calgary, Alberta

Correspondence and reprints: Dr Hugh Freeman, Gastroenterology, ACU F-137, University of British Columbia Hospital,

2211 Wesbrook Mall, Vancouver, British Columbia V6T 1W5. Telephone 604-822-7216, fax 604-822-7236

Received for publication December 9, 1998. Accepted March 31, 1999 
$\mathrm{G}$ enetic or inherited factors appear to be critical in the pathogenesis of Crohn's disease. Several recent studies have described familial occurrences of inflammatory bowel disease, including Crohn's disease (1-8). A proband with newly diagnosed Crohn's disease has about a 10-fold or greater likelihood of having a positive family history of Crohn's disease (1). If there is a relative, particularly a sibling, with Crohn's disease, the risk of developing Crohn's disease has been described to be as much as 30-fold $(9,10)$.

These recent studies also indicate that Crohn's disease in families occurs at similar ages in the same generation, with a significant degree of concordance for disease location (1). Others have also provided evidence in familial Crohn's disease for similarities in disease location, extent, 'behaviour' (defined as inflammatory, fistulizing or stenotic) (11) and operative requirements $(2,5)$. In addition, familial cases may have a younger age at diagnosis, usually with small bowel involvement and stricturing disease (1).

Some familial studies have argued that there is a genetic basis in the pathogenesis of Crohn's disease but have not excluded a common environmental, particularly infectious, cause. In some studies, a strong case has been made in familial Crohn's disease for 'genetic anticipation' $(1,6,8)$. In this genetic hypothesis for parent-child pairs with a given disease, median age of onset (or diagnosis) of disease in the child has been estimated to be 16 years less than in the parent (8). However, as has been noted elsewhere (12), studies reporting this phenomenon of genetic anticipation in Crohn's disease have not necessarily excluded a cohort effect related to exposure at a specific time for a pathogenic environmental agent.

Although there are no studies to date on familial Crohn's disease in immigrants to Canada, the present report describes a unique Indo-Canadian family with three siblings who all developed penetrating or fistulizing disease in the small and large intestine following immigration to Canada in 1972 from Uganda. Almost two decades after the disease was diagnosed in these siblings, their father, also from Uganda, was found to have Crohn's disease.

\section{CASE PRESENTATIONS}

Table 1 compares clinical data of four members of an IndoCanadian family with Crohn's disease. All family members were born in Kampala, Uganda, and later immigrated to Canada in 1972. To date, one sister and the mother have no clinically evident disease. All patients were last reviewed in 1998.

Case 1: A 15-year-old girl developed abdominal pain, diarrhea and weight loss in 1977. Barium radiographic studies of the upper and lower gastrointestinal tracts done in Winnipeg revealed features of Crohn's disease. Treatment included intermittent courses of oral prednisone and sulphasalazine. In 1981, she moved to Calgary, Alberta, and, because of marked weight loss (ie, over $10 \mathrm{~kg}$ ), was admitted to Foothills Hospital in 1983 for parenteral nutrition. Barium and endoscopic studies confirmed the presence of Crohn's disease, and a perianal fistula with an abscess was also detected. She was treated with metronidazole. During a vacation in Vancouver, British Columbia, in 1984, abdominal pain, worsening diarrhea and weight loss developed. A left lower quadrant intra-abdominal abscess was diagnosed along with complex perianal fistulous disease. Gastroscopy and flexible sigmoidoscopy with biopsies of the stomach, small bowel and rectum were normal, but a hypaque enema revealed a proximal sigmoid fistula leading into an abscess cavity. Treatment included intravenous antibiotics, parenteral nutrition and percutaneous radiological catheter drainage. She was discharged on oral metronidazole. After her return to Calgary, she eventually had a right hemicolectomy in 1984, and removal of a rectal stump along with rectovaginal fistula in 1987. Since then, several colostomy revisions were done, and renal stones were surgically

TABLE 1

Summary of clinical features of an Indo-Canadian family with Crohn's disease (CD)

\begin{tabular}{|c|c|c|c|c|c|c|}
\hline Case & $\begin{array}{c}\text { Age arrived } \\
\text { in Canada (years) }\end{array}$ & $\begin{array}{c}\text { Age at CD } \\
\text { diagnosis (years) }\end{array}$ & $\begin{array}{l}\text { Years in Canada } \\
\text { before diagnosis }\end{array}$ & Sites of CD & Behaviour of CD & Perianal disease \\
\hline \multicolumn{7}{|c|}{$\begin{array}{l}\text { Second-generation } \\
\text { (born in Uganda) }\end{array}$} \\
\hline 1 & 10 & 15 & 5 & Ileum, colon & $\begin{array}{l}\text { Fistulizing or } \\
\text { penetrating }\end{array}$ & Yes \\
\hline 2 & 20 & 27 & 7 & Ileum, colon & $\begin{array}{l}\text { Fistulizing or } \\
\text { penetrating }\end{array}$ & Yes \\
\hline 3 & 14 & 25 & 11 & Ileum, colon & $\begin{array}{l}\text { Fistulizing or } \\
\text { penetrating }\end{array}$ & Yes \\
\hline \multicolumn{7}{|c|}{$\begin{array}{l}\text { First-generation } \\
\text { (born in Uganda) }\end{array}$} \\
\hline 4 & 47 & 76 & 26 & Ileum & $\begin{array}{l}\text { Stricturing or } \\
\text { stenosing }\end{array}$ & No \\
\hline
\end{tabular}

Antineutrophil cytoplasmic autoantibodies for all four patients were negative. Chest radiographs were normal, and acid-fast stains of biopsy materials were negative for all four patients at the time of publication 
removed in 1985. In 1990, barium studies were normal in Calgary, but endoscopic evaluation through the stoma at a Lower Mainland community hospital in 1997 showed inflammatory changes with granulomas. In 1998, she was last seen at the University of British Columbia Hospital during evaluation for a depressive illness; she was not receiving medications for Crohn's disease.

Case 2: A 27-year-old man developed abdominal pain and had a laparotomy in Winnipeg, Manitoba for suspected appendicitis in 1979. During surgery, an inflamed ileum suggested involvement with Crohn's disease. Rigid sigmoidoscopy and barium radiographic studies confirmed the presence of distal ileal disease, but the colon was normal. Treatment included sulphasalazine and, later, prednisone. He moved to Calgary but initially returned intermittently to Winnipeg for medical care until he required emergent admission to the Foothills Hospital in 1981 because of severe abdominal pain. An intra-abdominal abscess was diagnosed followed by incision, surgical catheter drainage and eventually an ileocolonic resection. Pathological studies showed typical histological changes of Crohn's disease in the small and large bowel with granulomas. In 1984, a perianal abscess was surgically drained and he was treated with oral metronidazole. In 1988, he moved to Vancouver and was seen at the University of British Columbia Hospital. His clinical course over the past 10 years has been complicated with multiple duodenal ulcers, ischiorectal abscesses necessitating surgical drainage, renal calculi and recurrent admissions for transient small bowel obstructions related to intra-abdominal adhesions. Treatment with various oral 5-aminosalicylates, prednisone, budesonide controlled ileal release, metronidazole and azathioprine have not significantly altered his clinical course.

Case 3: A 25-year-old man was seen in Calgary in 1983 with abdominal pain, diarrhea and weight loss. Following barium radiographic studies, Crohn's disease was diagnosed. In 1995, an ileocolonic resection was done at the Foothills Hospital, followed by a second small bowel resection a few months later. Pathological changes were characteristic of Crohn's disease with granulomas. In 1986, the patient moved to Vancouver, and colonoscopy at the University of British Columbia Hospital revealed numerous aphthoid and serpiginous ulcers in the colon and distal small intestine. Upper gastrointestinal endoscopy was normal. Mucosal biopsies showed inflammatory changes in the small and large bowel, but granulomas were not detected. Treatment included intermittent courses of prednisone and different 5-aminosalicylates. In 1998, an enterovesicle fistula was detected and resected at a Lower Mainland community hospital.

Case 4: A 76-year-old man, the father of the three siblings, was first seen in November 1998 with a three-week history of postprandial abdominal pain and constipation. His physical examination was normal, with no evidence of perianal disease. Blood tests and ultrasound were normal. Flexible sigmoidoscopy and rectal biopsy were normal. Barium studies of the upper and lower gastrointestinal tract revealed a

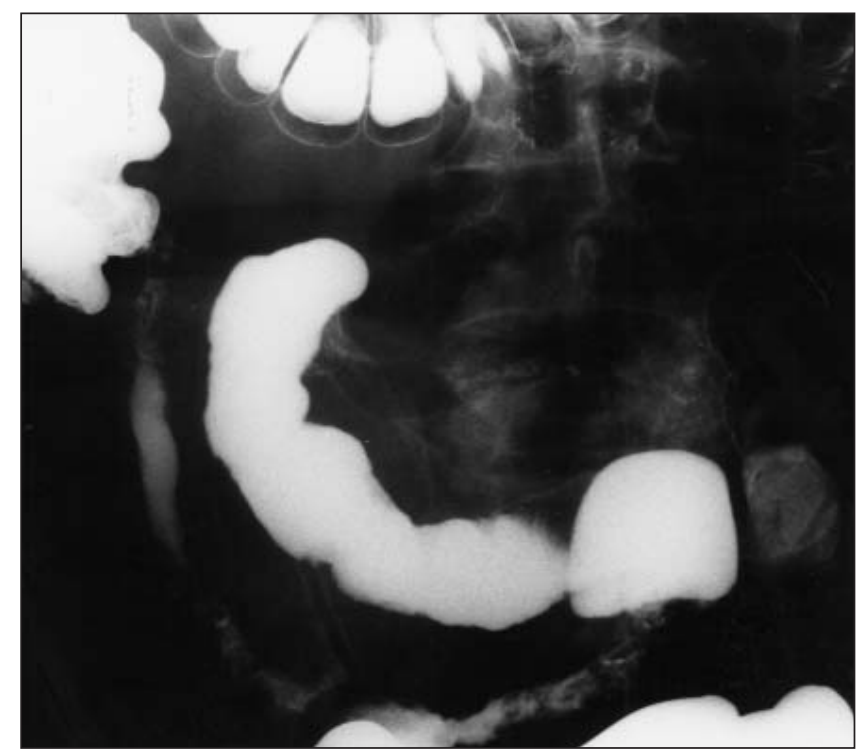

Figure 1) Barium radiograph in the father showing distal ileal Crohn's disease

$30 \mathrm{~cm}$ segment of stenotic and ulcerated distal ileum, typical of Crohn's disease (Figure 1). Treatment to date has included an oral 5-aminosalicylate.

\section{DISCUSSION}

This report documents the occurrence of Crohn's disease in an immigrant family, initially detected in three siblings after residence in Canada for six to 11 years, and later in a parent after residence in Canada for almost three decades. These observations in this family support the view that this disease arises in genetically predisposed individuals after exposure to some, as yet unknown, environmental factor. Genetic anticipation might also explain these findings (1). This denotes a reduction in the age of onset as a disease is passed in succeeding generations. Genetic anticipation has been most commonly reported in monogenic neurological diseases such as Huntington's disease and Friedreich's ataxia $(13,14)$. In these diseases, anticipation may have a specific molecular basis. Amplification of DNA triplet repeats in or adjacent to the disease gene occurs in successive generations; as a result, this DNA instability has been associated with an earlier age of onset in the younger generation (14). Although no molecular or gene defect for Crohn's disease has been defined to date, observations supporting the concept of anticipation have been reported in a number of other studies of parent-child pairs in familial Crohn's disease (1-8). In a European study (8) of 57 parent-first affected child pairs with familial Crohn's disease, for example, the median age of diagnosis was 16 years less in the child than in the parent (ie, with a range of four to 26 years) - similar to the generational difference in median age of this Indo-Canadian family of 19 years. This hypothesis of a genetically based generational difference in susceptibility to Crohn's disease is further strengthened by the observations in this family because there was a common date of 
migration to Canada. Theoretically, if there had been a common exposure to a similar environmental factor during a similar duration of time in Canada, then time to diagnosis would have been similar. Further studies that might identify molecular genetic factors that may be important in the pathogenesis of familial Crohn's disease are needed.

The different ages of appearance of Crohn's disease in this family also illustrate a potential difficulty in the detection and assessment of patients in studies that rely on the expression of phenotypic variables. Previous studies have illustrated the high degree of concordance in familial Crohn's disease for a number of clinical features, such as the site and type of behaviour of the disease $(1,2,5,6)$. In this family, the site of disease in the ileum and colon, and the tendency to present with fistulizing complications, including perianal sepsis, was quite striking and suggested a high degree of concordance in the three siblings. The father, however, who was diagnosed at an elderly age and followed for only a short period of time, has so far only documented fibrostenotic disease of the distal ileum and no evidence of perianal involvement. Thus, in clinical studies that rely on phenotypic characteristics, efforts to establish a family history of Crohn's disease have a number of inherent biases. First, ascertainment bias may be evident in a late affected

\section{REFERENCES}

1. Peeters M, Nevens H, Baert F, et al. Familial aggregation in Crohn's disease: increased age-adjusted risk and concordance in clinical characteristics. Gastroenterology 1996;111:597-603.

2. Colombel JF, Grandbastien B, Gower-Rousseau C, et al. Clinical characteristics of Crohn's disease in 72 families. Gastroenterology 1996;111:604-7.

3. Lee JCW, Lennard-Jones JE. Inflammatory bowel disease in 67 families each with three or more affected first-degree relatives. Gastroenterology 1996;111:587-96.

4. Polito JM, Childs B, Mellits ED, Tokayer AZ, Harris ML, Bayless TM. Crohn's disease: influence of age at diagnosis on site and clinical type of disease. Gastroenterology 1996;111:580-96.

5. Bayless TM, Tokayer AZ, Polito JM, Quaskey SA, Mellits ED, Harris ML. Crohn's disease: concordance for site and clinical type in affected family members - potential hereditary influences. Gastroenterology 1996;111:573-9.

6. Satsangi J, Grootscholten C, Holt H, Jewell DP. Clinical patterns of familial inflammatory bowel disease. Gut 1996;38:738-41.

7. Akolkar PN, Gulwani-Akolkar B, Heresbach D, et al. Differences in risk of Crohn's disease in offspring of mothers and fathers with inflammatory bowel disease. Am J Gastroenterol 1997;92:2241-4.

8. Grandbastien B, Peeters M, Franchimont D, et al. Anticipation in familial Crohn's disease. Gut 1998;42:170-4.

9. Mayberry JF, Rhodes J, Newcombe RG. Familial prevalence of inflammatory bowel disease in relatives of patients with Crohn's disease. Br Med J 1980;280:84.

10. Fielding JF. The relative risk of inflammatory bowel disease among generation because time may be required before a diagnosis can be established or clinical features are expressed $(15,16)$. Although appreciated by clinicians in responding to issues raised by prospective parents, the family presented here further illustrates that the converse may also be true - similar issues may arise for older generations. In previous studies, the mean age of diagnosis in the later generation was often over 30 years, usually higher than the mean ages of sporadic cases $(1,6)$. It has been suggested $(17)$ that this preferential ascertainment of parents with a late age at diagnosis may reflect a different form of selection bias, with less recruitment of parents with an early onset of disease and reduced fertility. Perhaps, in the absence of a molecular marker or gene for Crohn's disease, other seromarkers that have already been explored in targeted groups, including those with familial disease, such pancreatic autoantibodies (18), neutrophil autoantibodies (antineutrophil cytoplasmic antibodies) (19) or anti-Saccharomyces cerevisiae mannan antibodies (20) may assist in precise phenotypic detection of genetically susceptible patients.

ACKNOWLEDGEMENT: The authors are grateful to Dr MHA Rasool for his referral of the father of this family for evaluation.

parents and siblings of Crohn's disease patients. J Clin Gastroenterol 1986;8:655-7.

11. Sachar DB, Andrews H, Farmer RG, et al. Proposed classification of patient subgroups in Crohn's disease. Working Team Report 4. Gastroenterol Int 1992;3:141-54.

12. Sachar DB. Crohn's disease: A family affair. Gastroenterology 1996;111:813-25.

13. Ranen NG, Stine OC, Abbott MH. Anticipation and instability of IT-15 (CAG)n repeats in parent-offspring pairs with Huntington disease. Am J Hum Genet 1995;57:593-602.

14. Campuzano V, Montermini L, Molto MD. Friederich's ataxia: autosomal recessive disease caused by an intronic GAA triplet repeat expansion. Science 1996;271:1423-7.

15. Frisch M, Olsen J, Andersen PK. Follow-up time bias and Crohn's disease. Lancet 1996;347:1551.

16. Inskip H, Coggon D, Osmond C. Follow-up time bias and Crohn's disease. Lancet 1996;347:1551.

17. Fraser FC. Follow-up time bias and Crohn's disease. Lancet 1996;347:1552.

18. Seibold F, Mork H, Tanza S, et al. Pancreatic autoantibodies in Crohn's disease: a family study. Gut 1997;40:481-4.

19. Freeman HJ. Inflammatory bowel diseases in Indo-Canadians with and without antineutrophil cytoplasmic antibodies. Can J Gastroenterol 2000;14:21-6.

20. Sendid B, Quinton JF, Charrier G, et al. Anti-Saccharomyces cerevisiae mannan antibodies in familial Crohn's disease. Am J Gastroenterol 1998;93:1306-10. 


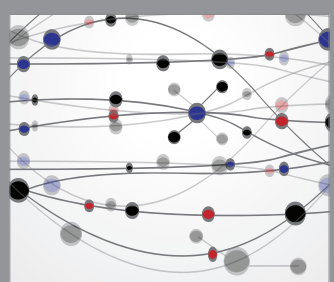

The Scientific World Journal
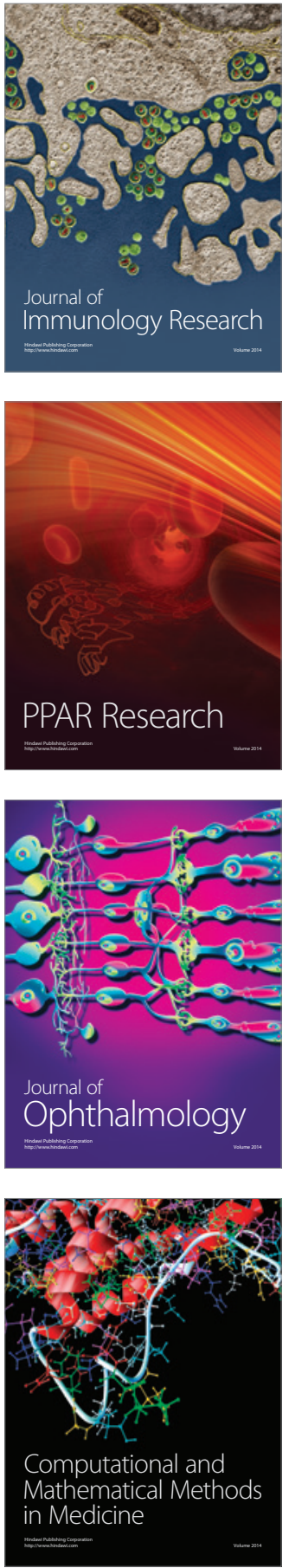

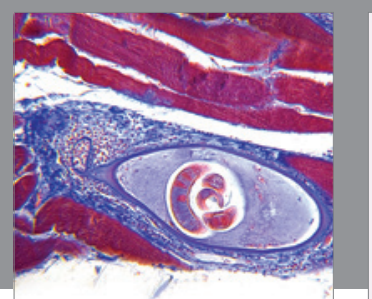

Gastroenterology Research and Practice

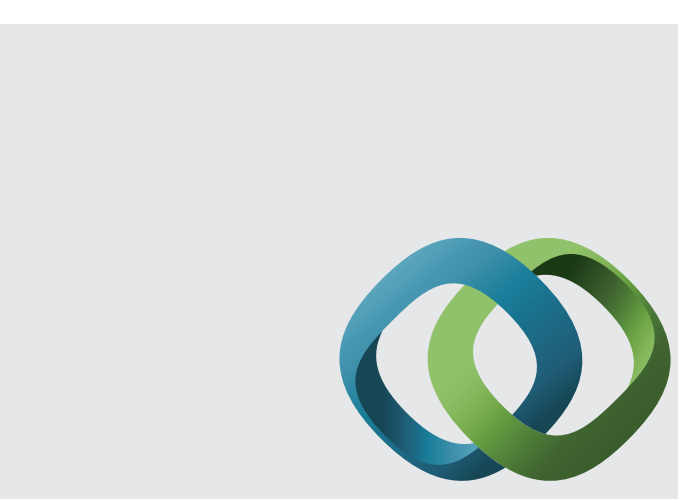

\section{Hindawi}

Submit your manuscripts at

http://www.hindawi.com
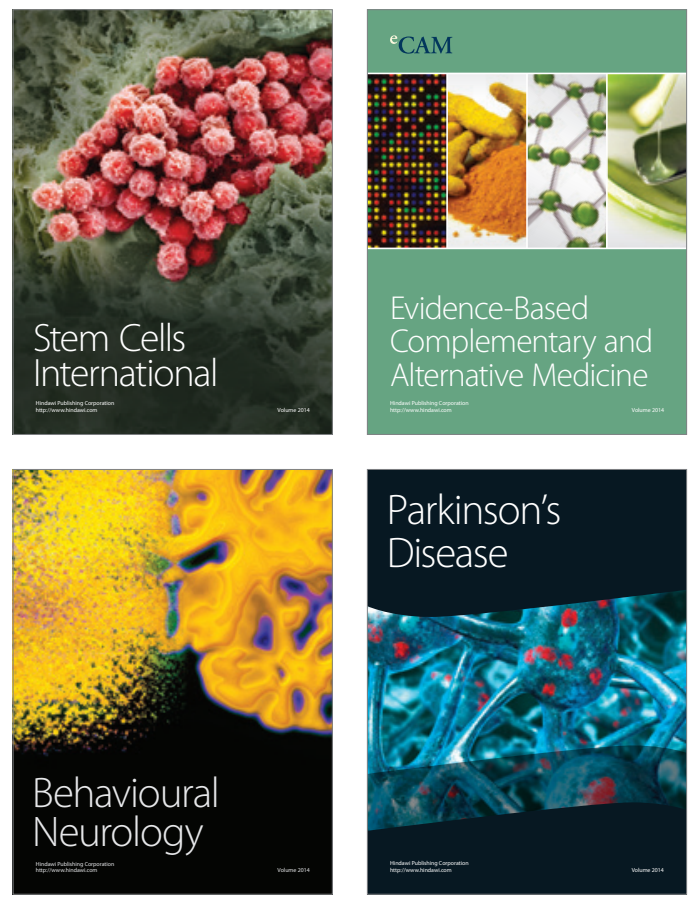
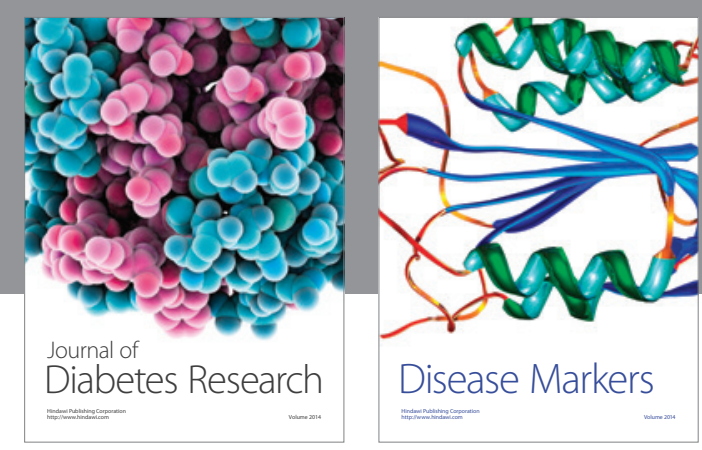

Disease Markers
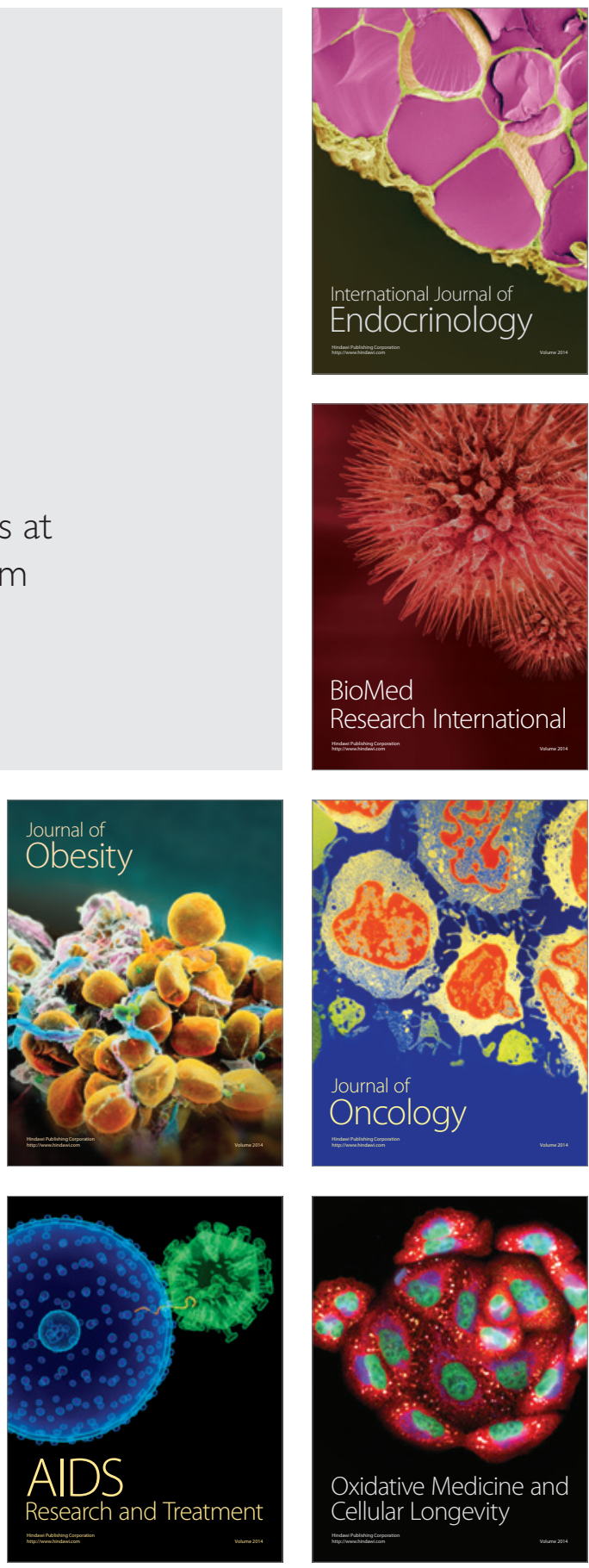